Journal of Business and Management Research

ISSN: 2382-5219(Print); 2467-9267(Online)

July 2016, Vol.1, No.2, pp.33-47

DOI: http://dx.doi.org/10.3126/jbmr.v1i2.15662

\title{
Family-Owned Firms between Agency Conflicts and Stewardship: Corporate Governance Factors Driving Firm Performance
}

\author{
Md. Nur Alam Siddik ${ }^{1} \&$ Sajal Kabiraj ${ }^{2 *}$ \\ ${ }^{1}$ Department of Finance and Banking, Begum Rokeya University, Rangpur, Bangladesh \\ ${ }^{2}$ International Business College, Dongbei University of Finance and Economics, Dalian, P.R.China
}

\begin{abstract}
The performance of family-owned firms has been driven by factors relating to family ownership, family leadership, and external supervision. In this paper, we offer an empirical study investigating the effects of those corporate governance concerns. To serve the purpose, we conducted a survey on 121 Chinese family-owned firms over the period of 2012-2014. Using pooled ordinary least square technique we find that family leadership and external supervision significantly influence the firms' Return on Assets (ROA) and Return on Equity (ROE) whereas family ownership significantly influences ROA, but not ROE. Findings also indicate that firm size, total assets, and solidity have significant impact on ROA and ROE. Discussing our findings in light of stewardship and agency theories, we especially supplement stewardship theory due to the close alignment between owners and managers in family-owned firms.
\end{abstract}

Keywords: Family business; corporate governance; stewardship theory; agency theory; performance

\section{Introduction}

In many countries, family-owned firms are crucial pillars of the economy. While the literature still lacks a clear definition of family-owned firms (Handler 1989; Winter, Fitzgerald, Heck, Haynes, \& Danes, 1998), these Family-owned firms like to maintain family control (Litz, 1995), in the form of unique, inseparable, synergistic resources and capabilities(Habbershon, Williams, \& MacMillan, 2003), thereby resulting in strategic decision making through family influences (Davis \& Tagiuri, 1989, Chua, Chrisman, \& Sharma, 1999).

Major operating decisions and plans for leadership succession are influenced by family members in management or on the board (Donckels \& Froehlich, 1991; International Family Enterprise Research Academy, 2003; Pistrui, Huang, Oksoy, Jing, \& Welsch, 2001). The performance of family-owned firms is driven by family and business factors (Berent-Braun \& Uhlaner, 2012; Dyer, 2006). A dyadic relationship between family and business reflects upon the existence of reciprocal economic and noneconomic values in family and business systems (Chrisman, Chua, \& Sharma, 2005; Gomez-Mejia,

* Corresponding Author

Email: skabiraj@dufe.edu.cn 
Cruz, Berrone, \& De Castro, 2011; Mitchell, Agle, \& Wood, 1997) and the corresponding corporate governance.

Corporate governance broadly refers to the rules, processes, or laws by which businesses are operated, regulated, and controlled. It covers the corresponding roles of the stakeholders as owners, managers, and outside directors and their impacts on firm performances. In this context, especially stewardship theory and agency theory have been used to explain firm behavior. According to stewardship theory (Davis, Schoorman, \& Donaldson, 1997; Donaldson, 1990; Donaldson \& Davis, 1991), managers and owners are motivated by values beyond economic private interest and often act with altruism for the welfare of the entire organization and its stakeholders. As stewardship and control propounded by stakeholders often differ comparing family-owned firms to large corporations, parts of the corporate governance literature related to family-owned firms analyze issues around kinship in management control and altruism (Castillo \& Wakefield, 2006; Eddleston \& Kellermanns, 2007, Keasey, Thompson, \& Wright, 2005; Monks \& Minow, 2004). Following agency theory (e.g., Eisenhardt, 1989; Jensen \& Meckling, 1976), the corporate governance relationships between family owners, minority shareholders, and managers are to be examined as typical agency issues or conflicts of interest which are addressed through a contract.

Aside of stewardship theory and agency theory, a growing body of corporate governance research addresses issues in the context of family owned businesses. For instance, Westhead and Howorth (2006) explore the relationship between family involvement in ownership and firm performance. They suggest that high levels of family ownership and management point to better firm performance. On the contrary, Cronqvist and Nilsson (2003) could not establish any correlation between family involvement in ownership and firm performance. Concerning family involvement in management, Maury (2006) and Villalonga and Amit (2006) point to family-owned firms performing better when a family member actively manages the firm as CEO or Chairman of the Board.

In this research, we offer an integrative empirical study investigating how corporate governance concerns affect the performance of family-owned firms. In particular, we aim to find out how family ownership, family leadership, and external supervisory factors influence a firm's performance indicators: Return on Assets (ROA) and Return on Equity (ROE).

The remainder of the paper is organized as follows: In the next section, we introduce our research model and derive our research hypotheses. We then outline our data collection among family-owned firms in China and the statistical methods which we employ to analyze the corresponding data. After presenting our results, we reflect our findings against the corporate governance literature and suggest directions for further research.

\section{Research Model and Approach}

We develop a research model to study how family ownership, family leadership, and external supervisory factors affect the performance of family-owned firms. The following section derives our research hypotheses, followed by a description of the model variables and our statistical approach.

\section{Research Hypotheses}

We analyze the potential impact of six factors influencing a family-owned firm's performance: (1) family ownership, (2) presence of a family CEO, (3) board size, (4) board structure (external board members), (5) presence of an audit committee, and (6) presence of external auditors in the audit committee.

Journal of Business and Management Research, July 2016, Vol. 1, No. 2 
Family Ownership. In the case of family-owned firms, ownership is often vested with family members. The family can make the decisions concerning the firm's non-human assets (Hart, 1995). Compared to other forms of firm ownership, family ownership appears to be a value enhancing factor (Adams, Almeida, \& Ferreira, 2009; Anderson \& Reeb, 2003; Barontini \& Caprio, 2006; Kowalewski, Talavera, \& Stetsyuk 2010; Maury, 2006). Following stewardship theory (Davis, Schoorman, \& Donaldson, 1997; Donaldson, 1990; Donaldson \& Davis, 1991), goal-alignment between the principals (e.g., firm owners) and stewards (e.g., CEOs) applies particularly to family-owned firms: Family owners often have a profound emotional investment and interest in their firms, as their fortune, personal contentment, and reputation are tied to the success of the firm. Thus, family owners are motivated by values beyond economic private interest, eventually leading to higher firm performance. According to agency theory (Jensen \& Meckling, 1976), equity ownership influences managers' risk-taking propensity (Keasey et al., 2005). With increased ownership, managers become risk averse. Hence, concentration of ownership among top managers typically leads to risk aversion, less pressure from outside investors, and less transparency and accountability (Carney, 2005). Entrepreneurs and managers of family-owned firms are often more prone to engage in managerial entrenchment to the detriment of the firm, which in turn results in weaker performance (Gomez-Mejia, Nunez-Nickel, \& Gutierrez, 2001; Thomsen \& Pedersen, 2000). The level of control may reduce ROA or ROE (Cronqvist \& Nilsson, 2003). We hypothesize:

H1. A single owner with more than $50 \%$ in equity positively affects the performance of familyowned firms.

Family CEO. Concerning the role of family members in executive positions, Adams et al. (2009), Anderson and Reeb (2003), and Kowalewski, Talavera and Stetsyuk (2010) find a significant positive effect of a CEO who is a member of an owner family, i.e., a Family CEO, on firm performance. Barontini and Caprio (2006) underline that family control is positive for European corporations, especially if the firm's founder exerts an active role as CEO or non-executive director. They could not find negative effects in case a family descendant assumes the role of CEO. On the contrary, Bennedsen, Nielsen, PerezGonzalez and Wolfenzon (2007), studying a dataset of family firms in Denmark, found that Family CEOs have a large negative impact on firm performance. We hypothesize:

$\mathrm{H} 2$. A family CEO positively affects the performance of family-owned firms.

Board of Directors - Size and Structure. Extensive research addresses the issue of board composition and financial firm performance (e.g., Bhagat, Bolton, \& Romano, 2008; Dalton, Daily, Ellstrand, \& Johnson, 1998; Dalton, Hitt, Certo, \& Dalton, 2008; Walsh \& Seward, 1990). In family-owned firms, boards have direct and elaborate insights into a firm's internal processes (Cowling, 2003). They typically contribute to strategic decision making (Fiegener, 2005), even though some exist only for names' sake (Brunninge \& Nordqvist, 2004). For boards to successfully monitor executive performance, their size and their structure deserve attention. Concerning board size, the general literature offers a mixed picture. Kajola (2008), Wynarczyk, Waston, Storey, Short and Keasey (1993), and Yermack (1996) point to small size boards being positively correlated to high firm performance, whereas Bokpin, KyereboahColeman and Aboagye (2006), Goodstein, Gautham and Boeker (1994), Eisenberg, Sundgren and Wells (1998), Mak and Kusnadi (2005), and Sanda, Mikailu and Garba (2005) suggest a positive correlation between larger boards and firm performance. However, none of these studies focuses on family-owned firms. For an investigation, we hypothesize:

H3. The board size positively affects the performance of family-owned firms. 
Concerning the board structure, previous research underlines that sufficient outside, non-executive ('independent') directors on the board, who are willing and able to monitor executive performance, improve firm performance (Bhagat et al., 2008; Nguyen \& Nielsen, 2009). Castillo and Wakefield (2006) find that a firm owner's perceived satisfaction with firm performance is positively related to the number of non-family board members, albeit the found significance was rather weak. In family-owned firms, especially family members in the executive management team rely on outside directors to perform the board's control task (Bammens, Voordeckers, \& van Gils, 2008). However, the independence of outside directors in the context of family-owned firms can be questioned (Anderson \& Reeb, 2003). Further, stockholders may benefit more from inside boards (Harris \& Raviv, 2008). In this debate, we hypothesize:

H4. Having outside directors on the board positively affects the performance of family-owned firms.

Audit Committee. Overseeing the financial reporting and accounting, an audit committee with external auditors secures regulatory compliance and thus should support a firm's risk management (e.g., Anderson, Mansi, \& Reeb, 2004). An audit committee typically performs three key roles in corporate governance. (1) It provides a platform apart from management where the accountants may discuss their concerns, (2) it accelerates communication flows among the board of directors, management, internal auditors, and independent accountants, and (3) it augments auditor independence from management by appointing, compensating, and overseeing the work of the independent accountants. However, Klein (2002) informs about a negative relationship between an audit committee's independence and firm performance. We hypothesize:

H5. Having an audit committee positively affects the performance of family-owned firms.

An audit committee generally has at least three members. Typically, two-thirds of the members are External Auditors in order to indicate the committee's independence, ensuring proper corporate governance practices. The chairman, appointed by the board, is usually one of the externals.

H6. Having external auditors on the audit committee positively affects the performance of familyowned firms.

\section{Model Variables}

Table 1 summarizes our research variables and the corresponding definitions. We model firm performance as dependent variable as ROA and ROE. The independent variables are coded as Ownership, Family CEO, Board Size, Outside Directors on the Board, Audit Committee, and External Auditors. As control variables we use Firm Size, Fixed Assets, Total Assets, Solidity, Nature of Firm, and Firm Age. Annual Investments, Employed Capital, and Net Profits are captured as descriptive variables.

Since we measure performance through ROA and ROE, we model the relationships between each of the two dependent variables and the independent variables, and control variables as shown below.

Model I

$$
\begin{aligned}
\text { ROA }= & \beta_{1}+\beta_{2} \text { Own }+\beta_{3} \text { F-CEO }+\beta_{4} \text { B-Size }+\beta_{5} \text { O-Dir }+\beta_{6} \text { AuCom }+\beta_{7} \text { O-AuCom }+ \\
& \beta_{8} \text { Emp-ln }+\beta_{9} H r-M+\beta_{10} \text { F-Size-ln }+\beta_{11} \text { FixAssets-ln }+\beta_{12} \text { TotAssets-ln }+\beta_{13} \\
& \text { Solidity-ln }+\beta_{14} \text { Nat-Firm }+\beta_{15} \text { F-Age }+\omega_{i t}
\end{aligned}
$$




\section{Model II}

$$
\begin{aligned}
R O E= & \beta_{1}+\beta_{2} \text { Own }+\beta_{3} \text { F-CEO }+\beta_{4} \text { B-Size }+\beta_{5} \text { O-Dir }+\beta_{6} \text { AuCom }+\beta_{7} \text { O-AuCom }+ \\
& \beta_{8} \text { Emp-ln }+\beta_{9} H r-M+\beta_{10} \text { F-Size-ln }+\beta_{11} \text { FixAssets-ln }+\beta_{12} \text { TotAssets-ln }+\beta_{13} \\
& \text { Solidity-ln }+\beta_{14} \text { Nat-Firm }+\beta_{15} \text { F-Age }+\omega_{i t}
\end{aligned}
$$

\begin{tabular}{|c|c|c|}
\hline Variable & Code & Description \\
\hline \multicolumn{3}{|c|}{ Dependent Variables } \\
\hline Return on Assets & ROA & $\begin{array}{l}\text { Net income / average total assets with average assets } \\
\text { calculated over two years }\end{array}$ \\
\hline Return on Equity & ROE & $\begin{array}{l}\text { Net income / average capital employed with two year average } \\
\text { for capital }\end{array}$ \\
\hline \multicolumn{3}{|c|}{ Independent Variables } \\
\hline Ownership & Own & $\begin{array}{l}\text { Dummy variable taking value ' } 1 \text { ' if largest single owner in } \\
\text { firm owning more than } 50 \% \text { of equity, ' } 0 \text { ' otherwise }\end{array}$ \\
\hline Family CEO & F-CEO & $\begin{array}{l}\text { Dummy variable taking value ' } 1 \text { ' if CEO is member of owner } \\
\text { family, ' } 0 \text { ' otherwise }\end{array}$ \\
\hline Board Size & B-Size & Number of board members \\
\hline $\begin{array}{l}\text { Outside Directors } \\
\text { on the Board }\end{array}$ & O-Dir & Number of outsiders on board \\
\hline Audit Committee & $\mathrm{AuCom}$ & $\begin{array}{l}\text { Dummy variable taking value ' } 1 \text { ' if firm has audit committee, } \\
\text { ' } 0 \text { ' otherwise }\end{array}$ \\
\hline External Auditors & O-AuCom & $\begin{array}{l}\text { Dummy variable taking value ' } 1 \text { ' if firm has external auditors } \\
\text { in audit committee, ' } 0 \text { ' otherwise }\end{array}$ \\
\hline Total Employees & Emp-ln & Logarithm of total employees in firm \\
\hline $\begin{array}{l}\text { Human Resource } \\
\text { Manager }\end{array}$ & $\mathrm{Hr}-\mathrm{M}$ & $\begin{array}{l}\text { Dummy variable taking value ' } 1 \text { ' if firm has personnel } \\
\text { manager / industrial relations manager / HR manager, ' } 0 \text { ' } \\
\text { otherwise }\end{array}$ \\
\hline \multicolumn{3}{|l|}{ Control Variables } \\
\hline Firm Size & F-Size-ln & Logarithm of annual turnover, measured in US\$ \\
\hline Fixed Assets & $\begin{array}{l}\text { FixAssets- } \\
\ln \end{array}$ & Logarithm of fixed assets, measured in US\$ \\
\hline Total Assets & $\begin{array}{l}\text { TotAssets- } \\
\ln \end{array}$ & Logarithm of total assets, measured in US\$ \\
\hline Solidity & Solidity-ln & Equity to total assets, measured in US\$ \\
\hline Nature of the Firm & Nat-Firm & $\begin{array}{l}\text { Dummy variable taking value ' } 1 \text { ' if firm revealing } \\
\text { manufacturing activity, ' } 0 \text { ' otherwise }\end{array}$ \\
\hline Firm Age & F-Age & $\begin{array}{l}\text { Dummy variable taking value ' } 1 \text { ' if firm founded > ten years } \\
\text { ago, ' } 0 \text { ' otherwise }\end{array}$ \\
\hline \multicolumn{3}{|c|}{ Descriptive Variables } \\
\hline Investments & Investm & Annual investments, measured in US\$ \\
\hline Employed Capital & Capital & Annual employed capital, measured in US\$ \\
\hline Net Profits & NetProfits & Annual net profits, measured in US\$ \\
\hline
\end{tabular}

Table 1

Variables 
In the above model, Own stands for Ownership, the F-CEO represents Family CEO, B-size is for Board Size, O-Dir is for Outside directors on the Board, AuCom stands for Audit committee, O-AuCom is external auditors, Emp-ln is for total employees and measured by logarithm of total employees in the firm, Hr-M is for Human Resource Manager, F-Size-ln is for Firm Size and measured by logarithm of annual turnover, FixAssets-ln is for Fixed assets and measured by logarithm of fixed assets, TotAssetsln stands for total assets and measured by logarithm of total assets, Solidity-ln stands for solidity, NatFirm is for nature of the firm, and F-age stands for the variable firm age.

\section{Statistical Approach}

As Best Linear Unbiased Estimator (BLUE), we apply Generalized Least Squares (GLS) to test the relationship between firm performance and corporate governance, which incorporates information about the errors and thereby making up for the inefficiency of Ordinary Least Squares (OLS). Since our method of fusing cross-sectional and time series data is sensitive to heteroscedasticity, we use white heteroscedastic-consistent standard errors and covariance. To address the problem of heterogeneity we include firm specific dummies with Fixed Effects. We also use Random Effects to address the heterogeneity and Panel-Corrected Standard Errors to ensure preciseness in the variance across units.

To handle complex error structures in Panel data, we estimate the coefficients by OLS and then compute Panels Corrected Standard Errors (Beck, Katz 1995). Since we use OLS coefficients to produce estimates of the residuals, it is possible that biases in OLS coefficients lead to problems with estimating standard errors. Therefore, we employ a regression with Panels Corrected Standard Errors. The significance of the Panels Corrected Standard Errors depends on the consistency of OLS point estimates.

We estimate the model using STATA 9.1. We correct panel data regression for the serial autocorrelation by the Cochrane-Orcutt method (Gujarati, 1995). The Hausman-Taylor estimation gives us the primary results. To examine the robustness of our main results, we estimate OLS with and without the control variables.

\section{Data Collection}

To test the above hypotheses, we collected primary data in China for 121 unlisted family-owned firms. We adopted purposive stratified random sampling to cherry-pick the family-owned firms. A structured questionnaire was sent, by means of email and also by post office, to the address of 150 family-owned firms. Among these 150 firms, 121 firms replied which means response rate was $81 \%$. We collected data for same firms for the period of 2012-2014 in terms of Chinese currency and then to generalize findings worldwide, Chinese currency was converted into U.S. dollar at the prevailing rate. To that end, we used balanced panel data for 121 family-owned firms in 17 Chinese states spread across five different regions (see Table 2). We pooled cross sectional observations for 15 parameters over the year of 2012- 2014.

\section{Results}

Out of the 121 firms studied, $86(71 \%)$ are involved in manufacturing activities. Of the sampled firms, $67(55 \%)$ have one family as single largest shareholder; the remaining $54(45 \%)$ have two to four families as major shareholders. The average firm age of the sampled firms is about eleven years and the mean ROA and ROE are about $28 \%$ and $66 \%$ respectively. The average firm size is of the order of US\$0.74

Journal of Business and Management Research, July 2016, Vol. 1, No. 2 
million annual turnover with an average net profit of about US\$0.027 million. Sample firms have an average capital employed of US\$0.46 million, average fixed assets of US\$0.362 million, average total assets of US\$0.248 million and an investment of US\$0.255 million. (For the descriptive statistics, see Table A1 in Appendix 1).

Table 2

Firms in Sample

\begin{tabular}{cllcc}
\hline No. & \multicolumn{1}{c}{ Region } & \multicolumn{1}{c}{ State } & Firms & Total in the Region \\
\hline 1 & North & Beijing & 5 & \\
3 & North & Tiajin & 5 & 18 \\
4 & North & Hebei & 8 & \\
5 & North East & Liaoning & 7 & 25 \\
6 & North East & Jilin & 6 & \\
7 & North East & Heilongjiang & 12 & \\
8 & East & Shanghai & 5 & \\
9 & East & Jiangsu & 4 & \\
10 & East & Zhejiang & 10 & \\
11 & East & Fujian & 8 & \\
12 & South Central & Henan & 7 & \\
13 & South Central & Guangdong & 5 & \\
14 & South Central & Hunan & 6 & \\
15 & South Central & Hainan & 6 & \\
16 & South West & Chongqing & 10 & \\
17 & South West & Sichuan & 12 & \\
& South West & Yunnan & 5 & \\
\hline
\end{tabular}

The average board size of the 121 firms studied is 10 . The number of Outside Directors on the Board is about two. $89 \%$ of the firms are managed by family CEOs. The mean of the number of employees is around 56 persons; $54 \%$ of firms have a Human Resource Manager or equivalent. Around $87 \%$ of firms have Audit Committees, and $81 \%$ of the firms studied have external members in their Audit Committee.

We ran our regressions separately for ROA and ROE as dependent variable as shown in the equations above ('Model I' and 'Model II').

As we used pooled data there might be presence of heteroscedasticity. Considering this issue, using Panels Corrected Standard Errors (PCSEs) we estimated the equations and findings are provided in Table 3. Also, to account for the preciseness in the variance across the family-owned firms, we checked our regression results for Panels Corrected Standard Errors (PCSEs). We provide the statistics for PraisWinsten regression (panel level heteroscedastic and correlated across panels) in Table 3.

Ownership (Own), defined as a single owner owning more than $50 \%$ of equity, is significant at the $1 \%$ level. Having a Family CEO (F-CEO) is significant at the $1 \%$ and 5\% levels. Having an Audit Committee (AuCom) is negatively significant at the $1 \%$ level. However, External Auditors (O-AuCom) positively influence performance at $1 \%$. The Board Size (B-Size) is distinctly significant at the $1 \%$ level. Table 4 summarizes our results with regard to the research hypotheses.

Table 3 

M. N. A. Siddik and S. Kabiraj

Regression with Panels Corrected Standard Errors (PCSEs)

\begin{tabular}{|c|c|c|c|c|}
\hline Model & $\begin{array}{c}\text { Panel-specific } \\
\text { AR(1) }\end{array}$ & $\begin{array}{c}\text { No Auto } \\
\text { Correlation }\end{array}$ & $\begin{array}{c}\text { Panel-Specific } \\
\text { AR(1) }\end{array}$ & $\begin{array}{l}\text { No Auto } \\
\text { Correlation }\end{array}$ \\
\hline $\begin{array}{l}\text { Dependent } \\
\text { Variable }\end{array}$ & ROA & ROA & ROE & ROE \\
\hline Constant & $\begin{array}{c}0.98 * * * \\
5.36\end{array}$ & $\begin{array}{c}0.96 * * * \\
10.04\end{array}$ & $\begin{array}{l}0.47 \\
0.70\end{array}$ & $\begin{array}{c}0.85 * * \\
2.02\end{array}$ \\
\hline Own & $\begin{array}{c}0.08 * * \\
2.27\end{array}$ & $\begin{array}{c}0.03 * * * \\
4.56\end{array}$ & $\begin{array}{l}0.05 \\
0.86\end{array}$ & $\begin{array}{c}0.10 * * * \\
4.49\end{array}$ \\
\hline F-CEO & $\begin{array}{c}0.11 * * * \\
2.72\end{array}$ & $\begin{array}{l}0.15 \\
0.50\end{array}$ & $\begin{array}{l}0.15 \\
.0 .90\end{array}$ & $\begin{array}{c}0.23 * * * \\
4.37\end{array}$ \\
\hline B-Size & $\begin{array}{l}0.04 \\
0.58\end{array}$ & $\begin{array}{c}0.01 * \\
1.62\end{array}$ & $\begin{array}{c}0.06^{* * * *} \\
5.20\end{array}$ & $\begin{array}{c}0.03 * * * \\
5.15\end{array}$ \\
\hline O-Dir & $\begin{array}{l}0.02 \\
1.08\end{array}$ & $\begin{array}{l}-0.02 \\
-1.40\end{array}$ & $\begin{array}{l}-0.04 \\
-1.16\end{array}$ & $\begin{array}{l}-0.07 \\
-0.71\end{array}$ \\
\hline AuCom & $\begin{array}{l}0.09 \\
0.23\end{array}$ & $\begin{array}{c}-0.04 * * \\
-0.97\end{array}$ & $\begin{array}{l}-0.08 \\
-0.12\end{array}$ & $\begin{array}{c}-0.22 * * * \\
-5.88\end{array}$ \\
\hline O-AuCom & $\begin{array}{l}0.02 \\
0.79\end{array}$ & $\begin{array}{c}0.06^{*} \\
1.57\end{array}$ & $\begin{array}{l}0.02 \\
0.24\end{array}$ & $\begin{array}{c}0.20 * * * \\
3.34\end{array}$ \\
\hline Emp-ln & $\begin{array}{c}0.04 * * \\
2.56\end{array}$ & $\begin{array}{c}0.05 * * * \\
11.14\end{array}$ & $\begin{array}{l}0.03 \\
0.80\end{array}$ & $\begin{array}{c}0.06^{* *} \\
0.52\end{array}$ \\
\hline $\mathrm{Hr}-\mathrm{M}$ & $\begin{array}{l}-0.01 \\
-0.57\end{array}$ & $\begin{array}{c}-0.03 * * \\
-2.27\end{array}$ & $\begin{array}{l}-0.09 \\
-1.93\end{array}$ & $\begin{array}{c}-0.05 * * * \\
-3.03\end{array}$ \\
\hline F-Size-ln & $\begin{array}{c}0.05 * * * \\
4.63\end{array}$ & $\begin{array}{c}0.04 * * * \\
9.27\end{array}$ & $\begin{array}{c}0.09 * * * \\
3.18\end{array}$ & $\begin{array}{c}0.21 * * * \\
6.50\end{array}$ \\
\hline FixAssets-ln & $\begin{array}{l}0.02 \\
0.36\end{array}$ & $\begin{array}{l}0.05 \\
0.25\end{array}$ & $\begin{array}{l}-0.03 \\
-0.94\end{array}$ & $\begin{array}{c}-0.76 * * * \\
-6.16\end{array}$ \\
\hline TotAssets-ln & $\begin{array}{c}-0.13 * * * \\
-12.12\end{array}$ & $\begin{array}{c}-0.11 * * * \\
-15.62\end{array}$ & $\begin{array}{c}-0.12 * * * \\
-3.80\end{array}$ & $\begin{array}{c}-0.19 * * * \\
-44.31\end{array}$ \\
\hline Solidity-ln & $\begin{array}{c}0.02^{*} \\
1.66\end{array}$ & $\begin{array}{l}0.01 \\
1.48\end{array}$ & $\begin{array}{c}-0.02 * * * \\
-3.23\end{array}$ & $\begin{array}{c}-0.04 * * * \\
-10.26\end{array}$ \\
\hline Nat-Firm & $\begin{array}{l}0.00 \\
0.01\end{array}$ & $\begin{array}{c}-0.02 * * * \\
-2.88\end{array}$ & $\begin{array}{c}0.32 * * * \\
4.27\end{array}$ & $\begin{array}{c}0.16^{* * * *} \\
46.19\end{array}$ \\
\hline F-Age & $\begin{array}{l}0.03 \\
1.31\end{array}$ & $\begin{array}{c}0.03 * * * \\
2.88\end{array}$ & $\begin{array}{l}0.01 \\
0.03\end{array}$ & $\begin{array}{c}0.01 * * * \\
12.49\end{array}$ \\
\hline Adj. $R^{2}$ & 0.74 & 0.40 & 0.41 & 0.33 \\
\hline F-Value / Wald Chi ${ }^{2}$ & 425.05 & 724062 & 37013 & 44706 \\
\hline Observations & 363 & 363 & 363 & 363 \\
\hline
\end{tabular}

Note: $* p<.1 ; * * p<.05 ; * * * p<.01$

The table reports (panel regression results) the estimated coefficients and $t$-values 
Table 4

Research Hypothesis Results

\begin{tabular}{|c|c|c|c|}
\hline Hypothesis & Description & $\begin{array}{l}\text { Result } \\
\text { ROA }\end{array}$ & $\begin{array}{l}\text { Result } \\
\text { ROE }\end{array}$ \\
\hline $\mathrm{H} 1$ & $\begin{array}{l}\text { A single owner with more than } 50 \% \text { in equity positively } \\
\text { affects the performance of family-owned firms. }\end{array}$ & Supported & Supported \\
\hline $\mathrm{H} 2$ & $\begin{array}{l}\text { A family CEO positively affects the performance of } \\
\text { family-owned firms. }\end{array}$ & Supported & Supported \\
\hline $\mathrm{H} 3$ & $\begin{array}{l}\text { The board size positively affects the performance of } \\
\text { family-owned firms. }\end{array}$ & Supported & Supported \\
\hline $\mathrm{H} 4$ & $\begin{array}{l}\text { Having outside directors on the board positively affects } \\
\text { the performance of family-owned firms. }\end{array}$ & Rejected & Rejected \\
\hline H5 & $\begin{array}{l}\text { Having an audit committee positively affects the } \\
\text { performance of family-owned firms. }\end{array}$ & Supported & Supported \\
\hline H6 & $\begin{array}{l}\text { Having external auditors in the audit committee } \\
\text { positively affects the performance of family-owned firms. }\end{array}$ & Supported & Supported \\
\hline
\end{tabular}

\section{Discussion}

Our research shows that family ownership, Family CEO, and Board Size all have a significant positive effect on firm performance. This supports our hypotheses and thus the literature from which we have derived the hypotheses. However, with regard to Family Ownership, we receive mixed results triggering a more detailed discussion.

In case of Family Ownership, we find positive impacts on both ROA and ROE as dependent variables. We find that equity ownership influences the risk aversion of firm management with regard to ROA (H1 supported for ROA; see also Keasey et al., 2005). This is in line with basic agency theory relating to owner-manager conflicts (Eisenhardt, 1989; Jensen \& Meckling, 1976). We also find such a positive effect on ROE (H1 supported for ROE). Thus, we disagree with Anderson and Reeb (2003), Barontini and Caprio (2006), Kowalewski, Talavera and Stetsyuk (2010), Maury (2006), and Schulze, Lubatkin and Dino (2003), who claim that the objectives of the owner and the firm are aligned in family-owned firms. Based on our results, we assume that family-owned firms possess distinct resources such as the social capital and stewardship behavior stemming from common ancestry and shared family identity (Corbetta \& Salvato, 2004), also supporting basic stewardship theory (Davis et al., 1997; Donaldson \& Davis, 1991). In line with Carney (2005), we suppose that such resources influence family-owned firm performance and form the comparative advantage family-owned firms have over large public corporations.

As we find that a Family $C E O$ has a positive effect on firm performance measured by ROA and ROE (H2 supported), we fall in line with Adams et al. (2009), Anderson and Reeb (2003), Barontini and Caprio (2006), Hansson, Liljeblom and Martikainen (2009), and Kowalewski, Talavera and Stetsyuk (2010), but contradict Bennedsen et al. (2007). Relating to agency theory, we suppose that when ownership and management reside within a family, agency costs are at least low. In this regard, we refer 
to Fama and Jensen (1983, p. 306), who state that "family members have advantages in monitoring and disciplining related decision agents" and disagree with Schulze et al. (2003) who attribute the reason for agency problems experienced in family-owned firms rooted in free riding.

We find that Board Size has a positive effect on both ROA and ROE (H3 supported). This supports Bokpin et al. (2006), Goodstein et al. (1994), Abor and Biekpe (2007), Kajola (2008), Wynarczyk et al. (1993), and Yermack (1996), but contradicts Eisenberg et al. (1998), Mak and Kusnadi (2005), and Sanda et al. (2005), who find that Board Size negatively affects firm performance. Based on our results, we assume that larger boards help family-owned firms in encouraging team development, facilitating inter-organizational links, and improving effective strategy making. We suppose that larger boards possess a wide range of expertise to guide the firms in making better decisions. Larger boards appear to make better use of the valuable resources and capabilities specific to family-owned firms including the overlapping responsibility of owners and managers, the sustained presence of family shareholders, entrepreneurship, and information advantages.

Concerning the Board Structure, our results shows having Outside Directors on the Board has no significant effect on ROA and ROE. In line with Brunninge, Nordqvist and Wiklund (2007), Castillo and Wakefield (2006), Core, Holthausen and Larcker (1999), and Nguyen and Nielsen (2009), we assume that Outside Directors on the Board add value in terms of cognitive diversity, relationships with external stakeholders, and independence from family matters. According to our results, having an Audit Committee negatively affects both ROA and ROE. This contradicts Kajola (2008), who could not find a significant relationship between ROE, board composition and audit committee. However, our findings are consistent with Anderson et al. (2004).

We show that having External Auditors has a positive influence on both ROA and ROE. We thus support Fan and Wong (2005), who suggest that external auditors perform an important governance role. We assume that they ascertain the validity and reliability of family-owned firms' financial statements.

\section{Contributions and Future Research}

While systematically examining the effects of corporate governance factors on the performance of family-owned firms, we contribute a theoretical and empirical link between corporate governance factors relating to family ownership, family leadership, and external supervision and the performance of familyowned firms. We explain the witnessed effects on firm performance by drawing upon stewardship theory and agency. As we see the concerns of owners as stewards and managers as principals are well aligned in family-owned business, we particularly supplement stewardship theory.

We base our findings on a broad sample containing non-listed family-owned firms of varying size, industries, governance, and locations across China. For further research we suggest studying the investigated corporate governance effects in different regions. In addition, incorporating listed companies in the sample could further enhance the findings as it would allow for a more-in-depth consideration of contractual issues grounded in agency theory. 


\section{References}

Abor, J. and Biekpe, N. (2007). Corporate governance, ownership structure and performance of SMEs in Ghana: Implications for financing opportunities.Corporate Governance: The international journal of business in society, 7(3), 288-300. http://dx.doi.org/10.1108/14720700710756562

Adams, R., Almeida, H., \& Ferreira, D. (2009). Understanding the relationship between founder-CEOs and firm performance. Journal of Empirical Finance, 16(1), 136-150. http://dx.doi.org/10.1016/j.jempfin.2008.05.002

Anderson, R., \& Reeb, D. (2003). Founding-family ownership and firm performance: Evidence from the S\&P 500. Journal of Finance, 58(3), 1301-1328. http://dx.doi.org/10.1111/1540-6261.00567

Anderson, R., Mansi, S., \& Reeb, D. (2004). Board characteristics, accounting report integrity and the cost of debt. Journal of Accounting and Economics, 37(3), 315-342. http://dx.doi.org/10.1016/j.jacceco.2004.01.004

Bammens, Y., Voordeckers, W., \& van Gils, A. (2008). Boards of directors in family firms: A generational perspective. Small Business Economics, 31(2), 163-180. http://dx.doi.org/10.1007/s11187-007

Barontini, R., \& Caprio, L. (2006). The effect of family control on firm value and performance: Evidence from continental Europe. European Financial Management, 12(5): 689-723. http://dx.doi.org/10.1111/j.1468-036X.2006.00273.x

Beck, N., \& Katz, J. (1995). What to do (and not to do) with time-series-cross-section data in comparative politics. American Political Science Review, 89(3), 634-647.

Bennedsen, M., Nielsen, K.N., Perez-Gonzalez, F., \& Wolfenzon, D. (2007). Inside the family firm: The role of families in succession decisions and performance. The Quarterly Journal of Economics, 122(2), 647-691. http://dx.doi.org/10.1162/qjec.122.2.647

Berent-Braun, M.M., \& Uhlaner, L.M. (2012). Responsible ownership behaviors and financial performance in family owned businesses, Journal of Small Business and Enterprise Development, 19(1), 20-38. http://dx.doi.org/10.1108/14626001211196389

Bhagat, S., Bolton, B., \& Romano, R. (2008). The promise and peril of corporate governance indices, Columbia Law Review, 108(8), 1803-1882.

Bokpin, G., Kyereboah-Coleman, A., \& Aboagye, A. (2006, July). Corporate governance and shareholder wealth maximization: Evidence from listed companies in Ghana. Paper presented at the 3rd African Finance Journal Conference. Accra, Ghana.

Brunninge, O., \& Nordqvist, M. (2004). Ownership structure, board composition and entrepreneurship: Evidence from family firms and venture-capital backed firms. International Journal of Entrepreneurial Behaviour and Research, 10(1/2), 85-105. http://dx.doi.org/10.1108/13552550410521399

Brunninge, O., Nordqvist. M., \& Wiklund, J. (2007). Corporate governance and strategic change in SMEs: The effects of ownership, board composition and top management teams. Small Business Economics, 29(3), 295-308. http://dx.doi.org/10.1007/s11187-006-9021-2

Carney, M. (2005). Corporate governance and competitive advantage in family-controlled firms. Entrepreneurship Theory \& Practice, 29(3), 249-265. http://dx.doi.org/10.1111/j.15406520.2005.00081.x

Castillo, J., \& Wakefield, M. (2006). An exploration of firm performance factors in family business: Do families value only the "Bottom Line"? Journal of Small Business Strategy, 17(2), 37-51. 
Chrisman, J., Chua, J., \& Sharma, P. (2005). Trends and directions in the development of a strategic management theory of the family Firm. Entrepreneurship Theory and Practice, 29(5), 555-576. http://dx.doi.org/10.1111/j.1540-6520.2005.00098.x

Chua, J., Chrisman, J., \& Sharma, P. (1999). Defining the family business by behavior. Entrepreneurship Theory \& Practice, 3(4), 19-39.

Corbetta, G., \& Salvato, C. (2004). Self-serving or self-actualising? Models of man and agency costs in different types of family firms: A commentary on "Comparing the agency costs of family and nonfamily firms: Conceptual issues and exploratory evidence". Entrepreneurship Theory and Practice, 28(4), 355-362. http://dx.doi.org/10.1111/j.1540-6520.2004.00050.x

Core, J., Holthausen, R., \& Larcker, D. (1999). Corporate governance, chief executive officer compensation, and firm performance. Journal of Financial Economics, 51(3), 371-406.

Cowling, M. (2003). Productivity and corporate governance in smaller firms. Small Business Economics, 20(4), 335-344. http://dx.doi.org/10.1016/S0304-405X(98)00058-0

Cronqvist, H., \& Nilsson, M. (2003). Agency costs of controlling minority shareholders. Journal of

Financial and Quantitative Analysis, 38(4), 695-719. http://dx.doi.org/10.2307/4126740

Dalton, D., Daily, C., Ellstrand, A., \& Johnson J. (1998). Board composition, leadership structure, and financial performance: Meta-analytic reviews and research agenda. Strategic Management Journal, 19(3), 269-290.

Dalton, D. R., Hitt, M. A., Certo, S. T., \& Dalton, C. M. (2007). 1 The Fundamental Agency Problem and Its Mitigation: Independence, Equity, and the Market for Corporate Control. The academy of management annals, 1(1), 1-64. http://dx.doi.org/10.2307/4126740

Davis, J., Schoorman, F., \& Donaldson, L. (1997). Toward a stewardship theory of management. The Academy of Management Review, 22(1), 20-47. http://dx.doi.org/10.5465/AMR.1997.9707180258

Davis, J., \& Tagiuri, R. (1989). The Advantages and Disadvantages of the Family Business, Owner Managed Business Institute, Reprinted in Ibrahim, AB and Ellis, W.(1994), Family Business Management, Kendall.

Donaldson, L. (1990). The Ethereal Hand: Organizational Economics and Management Theory, The Academy of Management Review, 15(3): 369-381. http://dx.doi.org/10.5465/AMR.1990.4308806

Donaldson, L., \& Davis, J. H. (1991). Stewardship Theory or Agency Theory: CEO Governance and Shareholder Returns, Australian Journal of Management, 16(1): 49-64. http://dx.doi.org/10.1177/031289629101600103

Donckels, R., \& Froehlich, E. (1991). Are Family Businesses Really Different? European Experiences from STRATOS, Family Business Review, 4(2): 149-160. http://dx.doi.org/10.1111/j.17416248.1991.00149.x

Dyer, W.G. (2006). Examining the "Family Effect" on Firm Performance, Family Business Review, 19(4): 253-273. http://dx.doi.org/10.1111/j.1741-6248.2006.00074.x

Eddleston, K., \& Kellermanns, F. (2007). Destructive and Productive Family Relationships: A Stewardship Theory Perspective, Journal of Business Venturing, 22(4): 545-565. http://dx.doi.org/10.1016/j.jbusvent.2006.06.004

Eisenberg, T., Sundgren, S., \& Wells, M. (1998). Larger Board Size and Decreasing Firm Value in Small Firms, Journal of Financial Economics, 48(1): 35-54. http://dx.doi.org/10.1016/S0304405X(98)00003-8

Eisenhardt, K.M. (1989). Agency Theory: An Assessment and Review, The Academy of Management Review, 14(1): 57-74. http://dx.doi.org/10.5465/AMR.1989.4279003

Fama, E., \& Jensen, M. (1983). Separation of Ownership and Control, Journal of Law and Economics, 26(2): 301-325.

Journal of Business and Management Research, July 2016, Vol. 1, No. 2 
Fan, J. \& Wong, T. (2005). Do External Auditors Perform a Corporate Governance Role in Emerging Markets? Evidence from East Asia, Journal of Accounting Research, 43(1): 35-72. http://dx.doi.org/10.1111/j.1475-679x.2004.00162.x

Fiegener, M. (2005). Determinants of Board Participation in the Strategic Decisions of Small Corporations, Entrepreneurship: Theory and Practice, 29(5): 627-650. http://dx.doi.org/10.1111/j.1540-6520.2005.00101.x

Gomez-Mejia, L., Nunez-Nickel, M., \& Gutierrez, I. (2001). The role of family ties in agency contracts, Academy of Management Journal, 44(1): 81-95. http://dx.doi.org.10.2307/3069338

Gomez-Mejia, L. R., Cruz, C., Berrone, P., \& De Castro, J. (2011). The bind that ties: Socioemotional wealth preservation in family firms. The academy of management annals, 5(1), 653-707. http://dx.doi.org.10.1080/19416520.2011.593320

Goodstein, J., Gautham, K., \& Boeker, W. (1994). The effects of board size and diversity on strategy change. Strategic Management Journal, 15(3), 241-250. http://dx.doi.org/10.1002/smj.4250150305

Gujarati, D. (1995). Basic Econometrics (3rd ed.). Columbus, OH: McGraw-Hill Companies.

Gujarati, D. N. (2007). Basic Econometrics. New Delhi: Tata McGraw-Hill Edition.

Habbershon, T., Williams, M., \& MacMillan, I. (2003). A unified systems perspective of family firm performance, Journal of Business Venturing, 18(4), 451-465. http://dx.doi.org/10.1016/S08339026(03)00053-3

Hansson, M., Liljeblom, E., \& Martikainen, M. (2009). Corporate governance and profitability in family SMEs. Working Paper. Retrieved from http://ssrn.com/abstract=1531638

Handler, W. (1989). Methodological issues and considerations in studying family businesses. Family Business Review, 2(3), 257-276. http://dx.doi.org/10.1111/j.1741-6248.1989.00257.x

Harris, M., \& Raviv, A. (2008). A Theory of board control and size. Review of Financial Studies, 21(4), 1797-1832. http://dx.doi.org/10.1093/rfs/hhl030

Hart, O. (1995). Corporate governance: Some theory and implications. The Economic Journal, 105(430), 678-689. http://dx.doi.org/10.2307/2235027

International Family Enterprise Research Academy (2003). Family businesses dominate. Family Business Review, 16(4), 235-239.

Jensen, M.C., \& Meckling, W.H. (1976). Theory of the firm: Managerial behavior, agency costs and ownership structure. Journal of Financial Economics, 3(4), 305-360. http://dx.doi.org/10.1016/0304$\underline{405 X(76) 90026-X}$

Kajola, S. (2008). Corporate governance and firm performance: The case of Nigerian listed firms. European Journal of Economics, Finance and Administrative Sciences, 14(14), 16-28.

Keasey, K., Thompson, S., \& Wright, M. (Eds.) (2005). Corporate governance: Accountability, enterprise and international comparisons. London: Wiley.

Klein, A. (2002). Audit committee, board of director characteristics and earnings management. Journal of Accounting and Economics, 33(3), 375-400. http://dx.doi.org/10.1016/S0165-4101(02)00059-9

Kowalewski, O., Talavera, O., \& Stetsyuk, I. (2010). Influence of family involvement in management and ownership on firm performance: Evidence from Poland. Family Business Review, 23(1), 45-59. http://dx.doi.org/10.1177/0894486509355803

Liang, N., \& Li, J. (1999, August). Board structure and firm performance: New evidence from China's private firms. Paper presented at the Academy of Management Annual Conference. Chicago, USA.

Litz, R. (1995). The family business: Toward definitional clarity. Family Business Review, 8(2), 71-82. http://dx.doi.org/10.1111/j.1741-6248.1995.00071.x 
Mak, Y., \& Kusnadi, Y. (2005). Size really matters: Further evidence on the negative relationship between board size and firm value. Pacific-Basin Finance Journal, 13(3), 301-318. http://dx.doi.org/10.1016/j.pacfin.2004.09.002

Maury, B. (2006). Family ownership and firm performance: Empirical evidence from Western European corporations. Journal of Corporate Finance, 12(2), 321-341. http://dx.doi.org/10.1016/j.jcorpfin.2005.02.002

Mitchell, R., Agle, B., \& Wood, D. (1997). Toward a theory of stakeholder identification and salience: Defining the principle of whom and what really counts. Academy of Management Review, 22(4), 853886. http://dx.doi.org/10.5465/AMR.1997.9711022105

Monks, R., \& Minow, N. (2004). Corporate Governance (3rd ed.). Oxford: Blackwell Business.

Nguyen, B., \& Nielsen, K. (2009). The Value of independent directors: Evidence from sudden deaths, (Working paper). Hong Kong: Chinese University of Hong Kong.

Pearson, K. (1896). Mathematical contributions to the theory of evolution-III, regression, heredity and panmixia. Philosophical Transactions of the Royal Society of London, Series A-187, 253-318. http://dx.doi.org/10.1098/rsta.1896.0007

Pistrui, D., Huang, W., Oksoy, D., Jing, Z., \& Welsch, H. (2001). Entrepreneurship in China: Characteristics, attributes, and family forces shaping the emerging private sector. Family Business Review, 14(2), 141-152. http://dx.doi.org/10.1111/j.1741-6248.2001.00141.x

Sanda, A., Mikailu, A., \& Garba, T. (2005). Corporate governance mechanisms and firm financial performance in Nigeria, AERC Research Paper 149, Nairobi.

Schulze, E., Lubatkin, M., \& Dino, R. (2003). Toward a theory of agency and altruism in family firms. Journal of Business Venturing, 18(4), 473-490. http://dx.doi.org/10.1016/S0833-9026(03)00054-5

Taylor, W. (1980). Small sample considerations in estimation from panel data. Journal of Econometrics, 13(2), 203-223.

Thomsen, S., \& Pedersen, T. (2000). Ownership Structure and Economic Performance in the Largest European Companies. Strategic Management Journal, 21(6), 689-705.

Villalonga, B., \& Amit, A. (2006). How do family ownership, control and management affect firm value? Journal of Financial Economics, 80(2), 385-417. http://dx.doi.org/10.1016/j.jfineco.2004.12-005

Walsh, J., \& Seward, J. (1990). On the efficiency of internal and external corporate Control mechanisms. Academy of Management Review, 15(3), 421-458. http://dx.doi.org/10.5465/AMR.1990.4308826

Westhead, P., \& Howorth, C. (2006). Ownership and management issues associated with family firm performance and company objectives. Family Business Review, 19(4), 301-316. http://dx.doi.org/10.1111/j.1741-6248.2006.00077.x

Winter, M., Fitzgerald, M., Heck, R., Haynes, G., \& Danes, S. (1998). Revisiting the study of family businesses: Methodological challenges, dilemmas, and alternative approaches. Family Business Review, 11(3), 239-252. http://dx.doi.org/10.1111/j.1741-6248.1998.00239.x

Wynarczyk, P., Waston. R, Storey, D., Short, H., \& Keasey, K. (1993). Managerial labour market in small to medium-sized enterprises. London: Routledge.

Yermack, D. (1996). Higher market valuation of companies with a small board of directors. Journal of Financial Economics, 40(2), 185-211. http://dx.doi.org/10.1016/0304-405X(95)00844-5 
Family-Owned Firms between Agency Conflicts 47

Appendix 1 - Descriptive Statistics

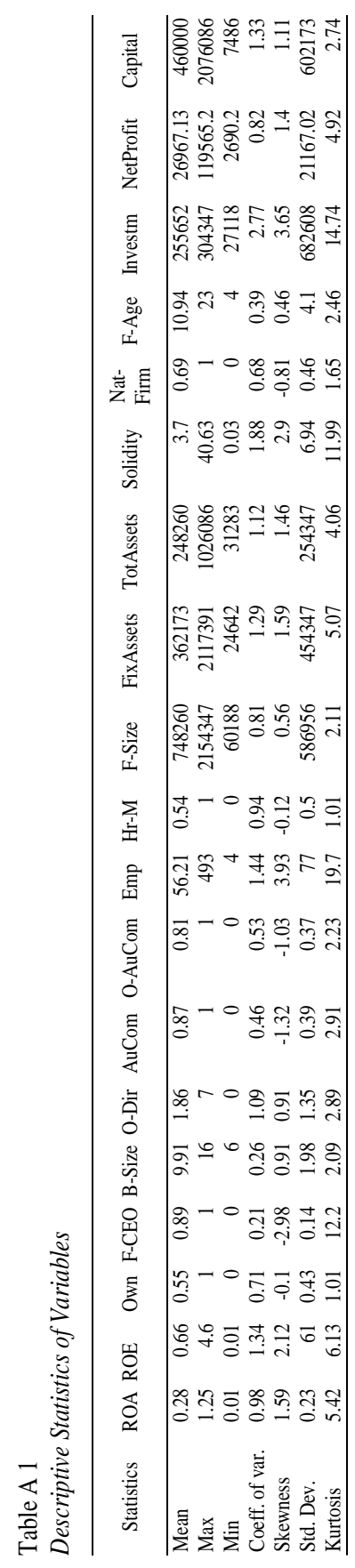

Journal of Business and Management Research, July 2016, Vol. 1, No. 2 